\title{
Reference biochemical values for three cultured Sparid fish: striped sea bream, Lithognathus mormyrus; common dentex, Dentex dentex; and gilthead sea bream, Sparus aurata
}

\author{
Hijran Yavuzcan Yildiz
}

Received: 29 April 2008 / Accepted: 20 May 2008 / Published online: 3 July 2008

(C) The Author(s) 2008

\begin{abstract}
The aim of the present study was to set up reference intervals for biochemical parameters in new candidate species of Mediterranean marine fish culturestriped sea bream, Lithognathus mormyrus and common dentex, Dentex dentex as well as traditionally cultured species-gilthead sea bream, Sparus aurata. The reference biochemical values were assessed for plasma cortisol, glucose, $\mathrm{Ca}$, inorganic $\mathrm{P}, \mathrm{Na}, \mathrm{K}, \mathrm{Cl}, \mathrm{C}$-reactive protein, hematocrit, and prothrombin time. The biochemical reference values established may allow important physiological decision in adaptation process of striped sea bream and common dentex as well as provide contribution to our present knowledge on gilthead sea bream physiology.
\end{abstract}

Keywords Lithognathus mormyrus · Dentex dentex.

Sparus aurata $\cdot$ Biochemical plasma intervals

\section{Introduction}

Species diversification is of major importance for marine Mediterranean aquaculture. Common dentex (Dentex dentex) and striped sea bream (Lithognathus mormyrus) have been considered as candidates to attain this goal. Success in introducing new species to aquaculture relies on a detailed knowledge of the physiology of the species. Historically, blood parameters have been studied and baseline values

H. Y. Yildiz $(\bowtie)$

Department of Fisheries and Aquaculture, Ankara University, 06110 Ankara, Turkey

e-mail: hijran.yavuzcan@agri.ankara.edu.tr have been established for many fish species (Hrubec et al. 2000; Burrows et al. 2001; Coz-Rakovac et al. 2005; Manera and Britti 2006; Svobodova et al. 2006; Tavares-Dias and Moraes 2007). Thus, hematological, biochemical, and hormonal parameters are useful indexes to monitor the health and physiological condition of fish, adaptation processes to various environmental influences, and stress effects of husbandry conditions in these aquatic vertebrates (Fanouraki et al. 2007). This study concerned with three Sparids: striped sea bream, L. mormyrus; common dentex, D. dentex; and gilthead sea bream, Sparus aurata. Although gilthead sea bream were studied with different aspects of its physiology (Ortuno et al. 2002a, b; Tort et al. 2002, 2003; Hernandez and Tort 2003; Alvarellos et al. 2006; Contessi et al. 2006; Roncarati et al. 2006), it would appear that at present, no study addressed the hematological, immunological, and hormonal reference intervals of common dentex and striped sea bream under culture conditions. In order to indicate the reliability of an estimate, the results of measurements were accompanied by confidence intervals in the present study. Hence, the reference intervals were calculated according to recommendations of the International Federation of Clinical Chemistry, as stated by Solberg (1994).

The aim of the present study was to determine reference intervals for plasma chemistry analytes in cultured striped sea bream (L. mormyrus), common dentex (D. dentex), and gilthead sea bream ( $S$. aurata) in order to provide information useful on physiological status of these species, particularly of common dentex and striped sea bream under rearing conditions. Comparison of three Sparids can be of great value to evaluate the adaptation process of new candidates - common dentex and striped sea bream for mariculture. 


\section{Material and methods}

Fish

Striped sea bream (L. mormyrus), common dentex (D. dentex), and gilthead sea bream ( $S$. aurata) sampled were held in the circular sea cages at a commercial farm (Bodrum, Turkey) at stocking density of $8-10 \mathrm{~kg} \mathrm{~m}^{-3}$. Twenty clinically healthy individuals of similar total length (14-18 cm) and weight (39-50 g) were selected for each species to blood sampling. They were fed with a commercial diet currently used for Sparid fish. Feeding was stopped $18 \mathrm{~h}$ prior to blood sampling. Careful netting and handling was implemented to minimize stress. Fish were not anesthetized due to the possible effects of anesthetics in plasma cortisol increase (Ortuno et al. 2002b), however, rapidly netted. Water temperature was around $18^{\circ} \mathrm{C}$, salinity $37-39 \mathrm{ppt}$, and dissolved oxygen 6-7 $\mathrm{mg} \mathrm{l}^{-1}$.

\section{Blood sampling}

Blood was collected from the caudal vein with heparinized syringes for the analysis to be performed, except for the prothrombin time (PT). Plasma was separated after centrifugation at 12,000 rpm and frozen until analysis.

\section{Analytical procedures}

Plasma cortisol was assessed using an EL commercial kit (DRG Diagnostics, Germany). Plasma glucose, Ca, inorganic $\mathrm{P}, \mathrm{Na}, \mathrm{K}, \mathrm{Cl}$, and $\mathrm{C}$-reactive protein (CRP) were determined using commercial kits (Olympus ISE, Ireland). Hematocrits were immediately determined by drawing well-mixed samples of blood into heparinized capillary tubes and centrifuging at 12,500 rpm for 4 min (Siwicki and Anderson 1993). Prothrombin time was determined by the Quick one-stage method, as stated by Konuk (1981) and Pavlidis et al. (1999).

\section{Statistical analysis}

The reference intervals bounded by the 2.5 th and 97.5 th were calculated by means of nonparametric estimates, together with the $95 \%$ confidence intervals as the assumption of normal distribution of samples was not answered.

\section{Results}

Reference intervals for plasma chemistry analytes were summarized for striped sea bream, L. morymrus; common dentex, D. dentex; and gilthead sea bream, $S$. aurata in Table 1.

\section{Discussion}

Hematological, biochemical, and endocrine parameters can be used as an effective method for monitoring physiological and pathological changes in fish. Alterations in the proportion of blood parameters are important indicators, reflecting diseases, and stress signals as well as adaptation process to different conditions. For this reason, reference intervals of biochemistry values were described for striped sea bass, L. morymrus and common dentex $D$. dentex which are candidates for Mediterranean mariculture as well as for gilthead sea bream, $S$. aurata in the present study.

Biochemical reference intervals of three Sparid fish: common dentex, D. dentex; striped sea bream, L. mormyrus; and gilthead sea bream, S. aurata are similar to control, baseline, or resting values found in other marine fish species like red porgy, Pagrus pagrus (Fanouraki et al. 2007); red sea bream, Pagrus major (Biswas et al. 2006); sea bass, Dicentrarchus labrax (Pavlidis et al. 1999; Caruso et al. 2005); and turbot, Psetta maxima (Burrows et al. 2001). Furthermore, except electrolytes, the values measured in this study in general were not distinct from the range described for other freshwater fish species such as channel catfish, Ictalurus punctatus (Tavares-Dias and Moraes 2007); rainbow trout, Onchorynchus mykiss (Manera and Britti 2006); and tilapia, Oreochromis hybrid (Hrubec et al. 2000). Although the reference values as 95\% confidence interval for cortisol in common dentex and striped sea bream fell within the ranges found for other marine fish, median values of cortisol could be considered as high when compared to gilthead sea bream which is traditionally cultured species. Ortuno et al. (2002b) reported that plasma cortisol of gilthead sea bream significantly increased after exposure to $60 \mu \mathrm{ll}^{-1}$ 2-phenoxyethanol for $1 \mathrm{~h}$ but not in fish exposed to air for $2 \mathrm{~min}$. Considering this report and previous personal experience, fish were not anesthetized in this study. In the present study, measured parameters classically considered to be indicative of the stress response such as plasma cortisol, glucose, plasma electrolytes, and prothrombin time. Particularly, plasma cortisol is widely used as an indicator of primary stress response in fish (Pickering 1992). With this respect, the high values of cortisol in dentex and striped sea bream in the present study are possibly related with the stress response of these species to culture conditions. Thus, the plasma cortisol values of gilthead sea bream assessed in this study are highly low. Plasma glucose and hematocrit as well as electrolyte balance are considered to be valuable indicators of the secondary stress indicators of fish (Barton 
Table 1 Reference values expressed as mean, standard deviation (SD), and 95\% confidence interval for the estimated analytes in striped sea bream (L. mormyrus), common dentex (D. dentex), and gilthead sea bream (S. aurata)

\begin{tabular}{|c|c|c|c|c|c|}
\hline Analytes & $\operatorname{Mean}(\chi)$ & SD & $95 \%$ confidence interval & Skewness & Kurtosis \\
\hline \multicolumn{6}{|c|}{ Plasma cortisol (ng ml${ }^{-1}$ ) } \\
\hline L. mormyrus & 17.87 & 3.17 & $14.93-20.81$ & 0.65 & -0.31 \\
\hline D. dentex & 15.20 & 3.62 & $11.84-18.55$ & 0.92 & -0.19 \\
\hline S. aurata & 4.61 & 0.88 & $3.68-5.54$ & 0.18 & -1.34 \\
\hline \multicolumn{6}{|c|}{ Plasma glucose $\left(\mathrm{mg} \mathrm{dl}^{-1}\right)$} \\
\hline L. mormyrus & 73.32 & 1.97 & $70.86-75.77$ & -0.96 & 1.95 \\
\hline D. dentex & 76.68 & 1.57 & $72.72-76.63$ & -1.39 & 2.12 \\
\hline S. aurata & 83.86 & 7.74 & $74.24-93.47$ & 0.68 & -1.97 \\
\hline \multicolumn{6}{|c|}{ Plasma Ca $\left(\mathrm{mg} \mathrm{dl}^{-1}\right)$} \\
\hline L. mormyrus & 10.58 & 0.42 & $10.04-11.11$ & -0.41 & 0.11 \\
\hline D. dentex & 13.97 & 0.44 & $13.42-14.53$ & 0.45 & -0.52 \\
\hline S. aurata & 11.28 & 0.35 & $10.84-11.72$ & 0.76 & -0.42 \\
\hline \multicolumn{6}{|c|}{ Plasma P (mg dl $\left.{ }^{-1}\right)$} \\
\hline L. mormyrus & 9.54 & 0.38 & $9.06-10.01$ & -0.61 & 0.43 \\
\hline D. dentex & 14.12 & 0.66 & $13.29-14.95$ & -1.34 & 2.59 \\
\hline S. aurata & 8.97 & 0.26 & $8.64-9.30$ & 1.33 & 1.63 \\
\hline \multicolumn{6}{|c|}{ Plasma $\mathrm{Na}\left(\mathrm{mmol} \mathrm{l}^{-1}\right)$} \\
\hline L. mormyrus & 192.4 & 2.07 & $189.82-194.97$ & 0.23 & -1.96 \\
\hline D. dentex & 210.60 & 2.08 & $208.02-213.17$ & -0.24 & -1.96 \\
\hline S. aurata & 186.4 & 3.57 & $181.95-190.84$ & -0.87 & 0.15 \\
\hline \multicolumn{6}{|c|}{ Plasma K (mmol l-1) } \\
\hline L. mormyrus & 2.20 & 0.09 & $2.07-2.32$ & -0.60 & -0.66 \\
\hline D. dentex & 4.09 & 0.43 & $3.56-4.63$ & 0.39 & -2.14 \\
\hline S. aurata & 2.75 & 0.15 & $2.57-2.94$ & -0.03 & -2.72 \\
\hline \multicolumn{6}{|c|}{ Plasma Cl (mmol l$\left.{ }^{-1}\right)$} \\
\hline L. mormyrus & 159.8 & 2.58 & $156.58-163.01$ & 0.36 & -2.41 \\
\hline D. dentex & 173.6 & 2.07 & $171.02-176.17$ & -0.24 & -1.96 \\
\hline S. aurata & 158.6 & 4.22 & $153.36-163.83$ & 0.83 & 0.58 \\
\hline \multicolumn{6}{|l|}{ Hematocrit (\%) } \\
\hline L. mormyrus & 28.87 & 4.15 & $26.24-31.51$ & 0.76 & 1.70 \\
\hline D. dentex & 34.02 & 5.76 & $30.70-37.35$ & -0.42 & 0.90 \\
\hline S. aurata & 29.23 & 3.95 & $25.35-33.42$ & 0.89 & 1.78 \\
\hline \multicolumn{6}{|c|}{ Prothrombin time (s) } \\
\hline L. mormyrus & 28.39 & 2.55 & $26.18-31.51$ & 0.55 & 1.20 \\
\hline D. dentex & 24.71 & 5.36 & $19.89-30.47$ & -0.67 & 0.88 \\
\hline S. aurata & 20.90 & 0.72 & $19.96-21.11$ & -0.33 & -0.90 \\
\hline \multicolumn{6}{|c|}{ C-reactive protein $\left(\mu \mathrm{g} \mathrm{ml}^{-1}\right)$} \\
\hline L. mormyrus & 48 & 0.81 & $37-58$ & 0.50 & -0.60 \\
\hline D. dentex & 82 & 0.84 & $71-92$ & -0.52 & -0.61 \\
\hline S. aurata & 72 & 0.82 & $61-82$ & -0.51 & -0.62 \\
\hline
\end{tabular}

and Iwama 1991). These secondary stress parameters of three Sparids did not show any extreme value or electrolyte balance disruption. However, plasma electrolytes of common dentex were higher than those of striped sea bream and gilthead sea bream. The values of plasma electrolytes in striped sea bream were similar to traditionally cultured gilthead sea bream. It was stated by Fanouraki et al. (2007) that PT may be used as a reliable stress indicator. Gilthead sea bream displayed the shortest PT when compared to the dentex and striped sea bream. However, PT of gilthead sea bream was found to be higher than that of the values for the same species assessed by Pavlidis et al. (1999). The PT values of other studied species fell within the range of PT values of red porgy and dentex, stated by Pavlidis et al. (1999). It was also measured CRP as non-specific humoral immune component in three Sparid studied in this study. CRP is important in innate host defense, especially in lower vertebrates. There is lack of the CRP values in the cultured marine fish; however, the CRP values of common dentex, striped sea bream, and gilthead sea bream were similar to normal range of CRP values found in rainbow trout, $O$. mykiss sera (Kodama et al. 2004). 
Common dentex had been studied in terms of physiological responses to stressors (Morales et al. 2005) and photoperiod (Pavlidis et al. 1999). Gilthead sea bream had also been studied for different stressors effects on blood parameters (Tort et al. 2001, 2002; Ortuno et al. 2002a, b; Caruso et al. 2005); however, there is no any information about physiology of striped sea bream under culture conditions.

In conclusion, considering the similar interval values of blood chemistry in all three Sparids - common dentex, striped sea bream, and gilthead sea bream-it can be concluded that the physiological status of two alternative species as dentex and striped sea bream are normal to aquaculture and no indications for extreme sensitivity to culture conditions. However, when specifically considered the median values of plasma cortisol in striped sea bream and common dentex, increased sensitivity to culture may become important. Further work is still necessary to understand the different factors that may affect these parameters.

Acknowledgments The author is grateful to Turkish Scientific and Technical Council (TUBITAK) as the analysis in this study were performed by means of the kits provided for the research project (1060257) supported by TUBITAK. The author thanks the company of Kilic Deniz Urunleri AS for providing fish and technical assistance.

Open Access This article is distributed under the terms of the Creative Commons Attribution Noncommercial License which permits any noncommercial use, distribution, and reproduction in any medium, provided the original author(s) and source are credited.

\section{References}

Alvarellos SS, Polakof S, Arjona FJ, Kleszynska A, Martin del Rio PM, Miguez JM, Soengas JL, Mancera JM (2006) Osmoregulatory and metabolic changes in the gilthead sea bream Sparus auratus after arginine vasotocin (AVT) treatment. Gen Comp Endocrinol 148:348-358 doi:10.1016/j.ygcen.2006. 04.005

Barton I, Iwama GK (1991) Physiological changes in fish from stress in aquaculture with emphasis on the response and effects of corticosteroids. Annu Rev Fish Dis 1:3-26 doi:10.1016/09598030(91)90019-G

Biswas AK, Seoka M, Takii K, Maita M, Kumai H (2006) Stress response of red sea bream Pagrus major to acute handling and chronic photoperiod manipulation. Aquaculture 252:566-572 doi:10.1016/j.aquaculture.2005.06.043

Burrows AS, Fletcher TC, Manning MJ (2001) Haematology of the turbot, Psetta maxima (L.): ultrastructural, cytochemical and morphological properties of peripheral blood leococytes. J Appl Ichthyol 17:77-84 doi:10.1046/j.1439-0426.2001.00250.x

Caruso G, Genovese L, Maricchiolo G, Modica A (2005) Haematological, biochemical and immunological parameters as stress indicators in Dicentrarchus labrax and Sparus aurata farmed in off-shore cages. Aquac Int 13:67-73 doi:10.1007/s10499-0049031-5

Contessi B, Volpatti D, Gusmani L, Galeotti M (2006) Evaluation of immunological parameters in farmed gilthead sea bream, Sparus aurata L., before and during outbreaks of winter syndrome. J Fish Dis 29:683-690 doi:10.1111/j.13652761.2006.00765.x

Coz-Rakovac R, Strunjak-Perovic I, Hacmanjek M, Topic Popovic N, Lipej Z, Sostaric B (2005) Blood chemistry and histological properties of wild and cultured sea bass (Dicentrarchus labrax) in the North Adriatic Sea. Vet Res Commun 29:677-687 doi:10.1007/s11259-005-3684-z

Fanouraki E, Divanach P, Pavlidis M (2007) Baseline values for acute and chronic stress indicators in sexually indicators in sexually immature red porgy (Pagrus pagrus). Aquaculture 265:294-304 doi:10.1016/j.aquaculture.2007.01.006

Hernandez A, Tort L (2003) Annual variation of complement, lysozyme and haemagglutinin levels in serum of the gilthead sea bream Sparus aurata. Fish Shellfish Immunol 15:479-481 doi:10.1016/S1050-4648(03)00024-X

Hrubec TC, Cardinale JL, Smith SA (2000) Hematology and plasma chemistry reference intervals for cultured tilapia (Oreochromis hybrid). Vet Clin Pathol 29:7-12 doi:10.1111/j.1939-165X.2000. tb00389.x

Kodama H, Matsuoka Y, Tanaka Y, Liu Y, Iwasaki T, Watarai S (2004) Changes of C-reactive protein in rainbow trout (Onchorynchus mykiss) sera after exposure to anti-ectoparasitic chemicals used in aquaculture. Fish Shellfish Immunol 16:589-597 doi:10.1016/j. fsi.2003.09.007

Konuk T (1981) Pratik Fizyoloji 1(in Turkish). Ankara Uni, Ankara

Manera M, Britti D (2006) Assessment of blood chemistry normal ranges in rainbow trout. J Fish Biol 69:1427-1434 doi:10.1111/ j.1095-8649.2006.01205.x

Morales AE, Cardenete G, Abellan E, Garcia-Rejon L (2005) Stressrelated physiological responses to handling in common dentex (Dentex dentex Linnaeus, 1758). Aquac Res 36:33-40 doi:10.1111/j.1365-2109.2004.01180.x

Ortuno J, Esteban MA, Mesequer J (2002a) Effects of phenoxyethonol on the innate immune system of gilthead sea bream (Sparus aurata) exposed to crowding stress. Vet Immunol Immunopathol 89:29-36 doi:10.1016/S0165-2427(02)00183-6

Ortuno J, Esteban MA, Mesequer J (2002b) Lack of effect of combining different stressors on innate immune responses of sea bream (Sparus auratus L.). Vet Immunol Immunopathol 84:17-27 doi:10.1016/S0165-2427(01)00387-7

Pavlidis M, Berry M, Kokkari C, Kentouri M (1999) Prothrombin time, activated partial thromboplastin time and fibrinogen values in Mediterranean marine teleosts. Fish Physiol Biochem 21:335343 doi:10.1023/A:1007882020754

Pickering AD (1992) Rainbow trout husbandry: management of the stress response. Aquaculture 100:125-139 doi:10.1016/00448486(92)90354-N

Roncarati A, Melotti P, Dees A, Mordenti O, Angelotti L (2006) Welfare status of cultured sea bass (Dicentrarchus labrax L.) and sea bream (Sparus aurata L.) assessed by blood parameters and tissue characteristics. J Appl Ichthyol 22:225-234 doi:10.1111/ j.1439-0426.2006.00741.x

Siwicki AK, Anderson DP (1993) Immunostimulation in fish: measuring the effects of stimulants by serological and immunological methods. The Nordic Symposium on Fish Immunology, Lysekil, 19-22 May, Sweden

Solberg HE (2004) The IFCC recommendation on estimation of reference intervals. The RefVal prog. Clin Chem Lab Med 42:710-714 doi:10.1515/CCLM.2004.121

Svobodova Z, Vykusova B, Modra H, Jarkovsky J, Smutna M (2006) Haematological and biochemical profile of harvest-size carp 
during harvest and post-harvest storage. Aquac Res 37:959-965 doi:10.1111/j.1365-2109.2006.01511.x

Tavares-Dias M, Moraes FR (2007) Haematological and biochemical reference intervals for farmed channel catfish. J Fish Biol 71:383-388 doi:10.1111/j.1095-8649.2007.01494.x

Tort L, Montero D, Robaina L, Fernández-Palacios H, Izquierdo MS (2001) Consistency of stress response to repeated handling in the gilthead sea bream, Sparus aurata. Aquac Res 32:593-598 doi:10.1046/j.1365-2109.2001.00607.x
Tort L, Puigcerver M, Crespo S, Padrós F (2002) Cortisol and haematological response in sea bream and trout subjected to the anaesthetics clove oil and 2-phenoxyethanol. Aquac Res 33:907910 doi:10.1046/j.1365-2109.2002.00741.x

Tort L, Rotllant J, Liarte C, Acerete L, Hernandez A, Ceulemans S, Coutteau P, Padros F (2003) Effects of temperature decrease on feeding rates immune indicators and histopathological changes of gilthead sea bream Sparus aurata fed with an experimental diet. Aquaculture 229:5-65 